\title{
Acquired pendular nystagmus from cerebellar nodulus acute ischemic lesion
}

Figure MR

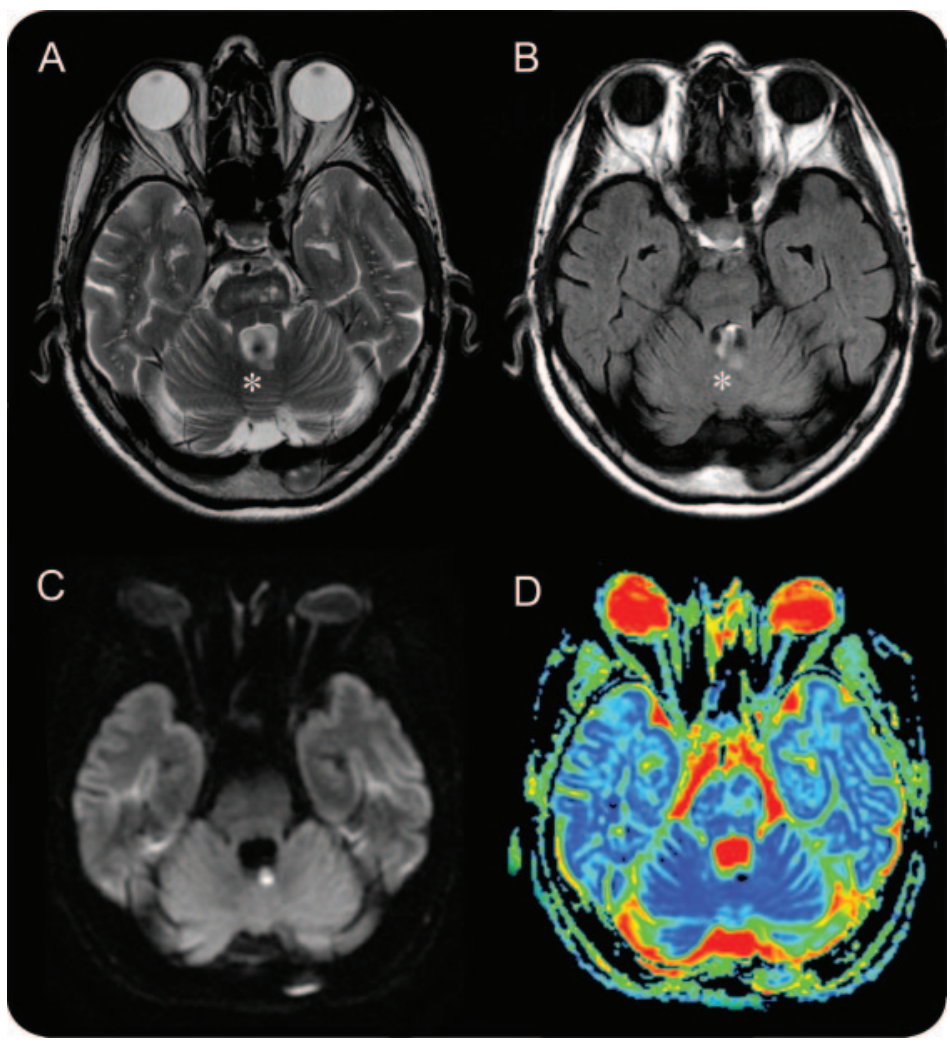

Fast spin-echo T2-weighted axial (A) and fluid-attenuated inversion recovery (B) MRI show a slight hyperintensity signal (asterisk) in the nodular portion of the cerebellar vermis. Diffusion-weighted imaging reveals a signal hyperintensity of the affected area (C), with a decrease in apparent diffusion coefficient, indicating cytotoxic edema (D).

A 71-year-old woman developed acute ataxia and oscillopsia, with underlying horizontal, binocular, conjugate pendular nystagmus (PN), with an amplitude of $4^{\circ}$ in both eyes and a $3 \mathrm{~Hz}$ frequency, without gaze-evoked components.

Brain MRI detected an altered signal in the nodular portion of cerebellar vermis, indicating cytotoxic edema (figure), due to an ischemic lesion.

Acquired PN has been traditionally attributed to "Guillain-Mollaret triangle" lesions. Recently, a neural integrator has been hypothesized in the brainstem, which guarantee the ability to hold steady eccentric gaze, whose disruption may give rise to PN. ${ }^{1}$

This case supports the contribution of vestibulocerebellum, mainly the nodulus, to modulate such neural network. ${ }^{2}$

Eugenia Rota, MD, Nicola Morelli, MD, Paolo Immovilli, MD, Fabiola Magnifico, MD, Piacenza;

Girolamo Crisi, MD, Parma; Donata Guidetti, MD, Piacenza, Italy

The authors report no disclosures relevant to the manuscript. Go to Neurology.org for full disclosures.

Correspondence \& reprint requests to Dr. Rota: eugenia.rota.md@gmail.com

1. Das VE, Oruganti P, Kramer PD, Leigh RJ. Experimental tests of a neural-network model for ocular oscillations caused by disease of central myelin. Exp Brain Res 2000;133:189-197.

2. Kheradmand A, Zee DS. Cerebellum and ocular motor control. Front Neurol 2011;2:53. 


\section{Neurology}

\section{Acquired pendular nystagmus from cerebellar nodulus acute ischemic lesion}

Eugenia Rota, Nicola Morelli, Paolo Immovilli, et al.

Neurology 2012;79;832

DOI 10.1212/WNL.0b013e3182661fab

This information is current as of August 20, 2012

\section{Updated Information \&} Services

References

Subspecialty Collections

Permissions \& Licensing

Reprints including high resolution figures, can be found at: http://n.neurology.org/content/79/8/832.full

This article cites 2 articles, 0 of which you can access for free at: http://n.neurology.org/content/79/8/832.full\#ref-list-1

This article, along with others on similar topics, appears in the following collection(s):

\section{All Cerebrovascular disease/Stroke}

http://n.neurology.org/cgi/collection/all_cerebrovascular_disease_strok e

All Clinical Neurology

http://n.neurology.org/cgi/collection/all_clinical_neurology

Nystagmus

http://n.neurology.org/cgi/collection/nystagmus

Information about reproducing this article in parts (figures,tables) or in its entirety can be found online at:

http://www.neurology.org/about/about_the_journal\#permissions

Information about ordering reprints can be found online:

http://n.neurology.org/subscribers/advertise

Neurology ${ }^{\circledR}$ is the official journal of the American Academy of Neurology. Published continuously since 1951, it is now a weekly with 48 issues per year. Copyright Copyright $@ 2012$ by AAN Enterprises, Inc.. All rights reserved. Print ISSN: 0028-3878. Online ISSN: 1526-632X.

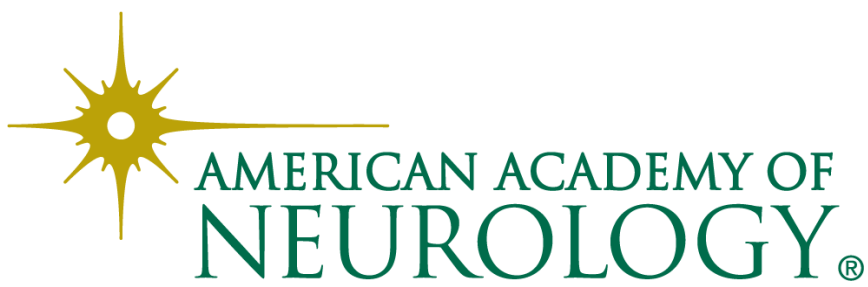

